\title{
Feminism and New Materialism: The Matter of Fluidity
}

\section{Elizabeth Stephens}

It is perhaps appropriate that the concept of fluidity should hold such an ambiguous and indeterminate position in contemporary critical theory. Studies of particular bodily fluids - such as tears (Lutz, 2001; Elkins, 2001), menstrual blood (Bobel, 2010; Rosewarne, 2012), breast milk (Giles, 2003) and female ejaculate (Bell, 2010) - have been of central importance to critical theory, in general, and to queer and gender studies, in particular. ${ }^{1}$ Despite this focus on particular bodily fluids, the concept of fluidity itself remains strangely uninterrogated. This is particularly strange is we consider how ubiquitous references to identities and sexualities as "fluid and contingent" are in critical theory, usually set in contrast to a presumptive popular assumption that these are unproblematically "fixed and stable." In this oppositional relation, the "fixed" is invariably aligned with the conservative and normative, while the "fluid" is associated with the positive, progressive, and resistant. The binary of the "fixed" and the "fluid" plays a pivotal role in the conceptualisation of much of the work in queer and gender studies. And yet, despite this, what is meant by fluidity itself is rarely subject to examination.

The aim of this paper then is, in the first instance, to undertake such an interrogation. In order to re-examine the concept of fluidity - and to consider the inter-relationship between the conceptual, experiential, and material this concept invites us to consider - it will start by (re)turning to the foundational work on Luce Irigaray on this subject. Such a return is especially timely, given recently renewed debate about the relationship between the conceptual and material within contemporary critical theory as a whole, and within feminism is particular. Much of this work is associated with what has come to be referred to as "new materialism," although it should be recognised that the is no real agreement about what this term refers to: Jane Bennett's influential work on the "vibrancy" of matter, and Karen Barad's important work on "agential realism," are well-known and often-cited examples of the "material turn" in feminist theory, for instance, although neither identifies as a "new materialist." In this respect, feminist new materialism is like fluidity itself: it remains a constitutively ambiguous category, less a coherent disciplinary field than a collection of often 
contradictory or disparate works. ${ }^{2}$ Much of this work, however, shares a common critique of earlier feminist writing on the material, framing itself as a corrective to a critical tendency to neglect the material in favour of "cultural" or "postmodern" concerns. As Diana Coole and Samantha Frost write in the introduction to their edited collection New Materialisms, for instance, the purpose of the volume is to address the "neglect of ... material phenomena and processes" in cultural and critical theory, a field that "privileges language, discourse, culture and values" over the material $(2010$, p.3). While Coole and Frost define their work and approach in opposition to that of postmodern or poststructuralist theory, however, closer examination reveals an interesting point of convergence. Just as fluidity is often taken as an unproblematically positive term feminist and queer theory, so is materiality championed in "feminist new materialist" writing as a "universal and indisputable good" (Bruining, p.151). It is precisely in this respect that Irigaray's writing on fluidity has such an important and productive contribution to make to contemporary debates on these topics, problematising both the assumed distinction between the conceptual and material, on the one hand, and the widely-held assumption that any matter - such as bodily fluids - can be categorised as unequivocally positive, either in its cultural effects or experienced affects, on the other.

\section{Theoretical Flows: Irigaray's Fluidity}

The work of Luce Irigaray provides what remains one of the most sustained and detailed accounts of fluidity, both as a philosophical concept and as an embodied materiality. Indeed, for Irigaray, the material and the conceptual are mutually constitutive terms. In "The Mechanics of Fluids," she argues that the matter, and embodied experience, of fluidity provides a productive framework through which both to understand and to problematise the conditions in which femininity is excluded from the "ruling symbolics" and "proper order." The philosophical issues at stake for Irigaray in her discussion of fluidity, and driving the importance of its theorisation to her work, are evident from the opening lines of "The Mechanics of Fluids," which begins:

It is already getting around - at what rate? in what contexts? in spite of what resistances? - that women diffuse themselves according to modalities scarcely compatible with the framework of the ruling symbolics. Which doesn't happen without causing some turbulence, we might even say some whirlwinds, that ought to be reconfined within solid walls of principle, to keep them from spreading to infinity. Otherwise they might even go so far as to disturb that third agency designated as the 
real - a transgression and confusion of boundaries that it is important to restore to their proper order. $(1993$, p.106)

In this respect, while Irigaray's approach to fluidity may appear, at first glance, representative of the "cultural turn" by which the materiality of matter has come, according to feminist new materialism, to be overlooked, what is immediately apparent here is that, although framed as a philosophical problem, Irigaray's understanding of and interest in the fluid moves between consideration of its cultural function and its materiality - indeed, it is characteristic of its diffusion and capacity for disruption that fluidity causes a "confusion of boundaries" between these apparently binary possibilities. At the same time, however, it is important to recognise that in the questions with which Irigaray opens this essay, we also hear a cautionary note: according to whom is femininity so associated with a disruptive fluidity? To what extent is its transgressive potential always-already inscribed within the proper order as that which it constructs as its constitutive outside?

In this way, Irigaray's discussion of fluidity is framed not as an exploration of an aspect of feminine materiality or biology that is inherently positive and resistant to a dominant, phallocentric culture, and can thus be easily reclaimed as such, but rather as the very category by which the exclusion of the feminine is effected, the basis on which it is silenced as "the mute outside that sustains all systematicity" (1989, p.365). Feminine materiality and biology are not simply or unproblematically a source of difference or resistance; they are also the rationale for women's historical silencing and exclusion: "And there you have it," as she quotes Freud in "The Mechanics of Fluids," "that is why your daughters are dumb" (1993, p.112). ${ }^{3}$ Language here is both the mechanism by which women are excluded from the proper and exemplary of the systematicity with which women are incompatible - and in this respect, it is very like the association of femininity with fluidity. In framing her discussion of feminine fluidity as a philosophical and linguistic issue, then, Irigaray is not "privileging language" in a way that "encourages neglect of the material." On the contrary, it is precisely this opposition her work sets out to critique. As she questions pertinently at the start of "Mechanics of Fluids":

what division is being perpetuated here between a language that is always subject to the postulates of ideality and an empirics that has forfeited all symbolisation? And how can we fail to recognise that with respect to this caesura, to the schism 
that underwrites the purity of logic, language remains necessarily meta-" something"? (1993, p.107).

Against this tendency to see the ideal and the material, the abstract and the sensible, as two distinct and mutually exclusive things, Irigaray is instead interested in the way fluidity - whose impropriety resides, precisely, in its inability to be confined in or by neat definitional categories problematises such distinctions.

Thus what is immediately apparent in the way Irigaray frames her discussion of fluidity is that, firstly, the value Irigaray attributes to fluidity, and what she has to say about its relation to the feminine, is cautious and highly qualified. On the one hand, she is clearly and strongly invested in the idea that the association of femininity with fluidity has potential for productive and strategic appropriation, that it provides a means by which to disrupt, effectively, the ruling symbolics: it is that which "resists adequate symbolisation" and threatens to "jam the works of the theoretical machine" (1993, p.107). At the same time, as Irigaray immediately acknowledges, this understanding of both femininity and fluidity as inherently disruptive is itself a product of those same ruling symbolics, and thus consistent with - indeed an expression of - the constitutive exclusion of the feminine: the materiality of femininity is always already inscribed (or circumscribed) within phallocentric systems of language and thought, as their "projective map" or "geometrical prop" (1993, p.108).

For Irigaray, then, the association of fluidity with contingency and instability does not produce unvaryingly positive results but ones that are always highly contingent. Thus while Irigaray obviously recognises the importance for women in reclaiming and asserting the fluidity with which they have been traditionally associated, identifying this as a source of potential resistance, she is also very careful to note the dangers and pitfalls of this strategy, and the significance of negative cultural conditions in which such strategies are formulated. We see this in the way that she is concerned to show how limited - and limiting - the idea of fluidity, as conceptualised in and by a regime of "solids" can be. The fluid, she notes, poses certain dangers not only to the proper order but to those who would use it as a defiant source of difference: "it allows itself to be easily traversed by virtue of its conductivity ... it mixes with bodies of a like state, sometimes dilutes itself in them in an almost homogeneous manner" (1993, p.111). 
For this reason, Irigaray's understanding of fluidity as a potential site of difference and resistance never assumes the biological to be a pure source of difference, experienced outside its wider cultural context; rather, as she shows, it is always interrelated to the cultural and conceptual. The contingency of the fluid has the potential to be both positive and negative. Thus while the cultural construction of femininity as incompatible with and disruptive of "the proper order" of things makes fluidity a productive site of appropriation and resistance, it is never a pure or unadulterated source of difference. Accordingly, Irigaray's approach to fluidity is a strategic one, as she explains in "The Power of Discourse." Here she speaks of "the necessity of 'reopening' the figures of philosophical discourse," and suggests that "one way [to do this] is to interrogate the conditions under which systematicity itself is possible ... how the break with material continguity is made, ... how the system is put together" (1993, p.74). This is a very close rearticulation of her opening statements in "The Mechanics of Fluids." Irigaray's approach could thus be most succinctly characterised as a strategic appropriation of traditional figures and representations of femininity designed to bring about their deconstruction, by exposing the limits and internal contradictions not simply in particular structures of language or philosophy but in their very systematicity. In this way, Irigaray's theorisation of fluidity continually moves between the material and the conceptual, seeing these as interconnected and mutually constitutive categories that need to be examined in relation to one another. Accordingly, her discussion of fluidity as a conceptual category is always directly related to the materiality of bodily fluids in a way that problematises attempts to speak of the material and conceptual as though they were opposing terms.

This problematics between "a language that is always subject to the postulates of ideality and an empirics that has forfeited all symbolisation" has been central to the reception of Irigaray's work in Anglophone feminism. While Irigaray's work - and especially her idea of "writing the body" - was enormously influential for a generation of feminists who were inspired and enabled by it, it was also and simultaneously the object of trenchant critique. Interestingly, the terms of this debate anticipate many of the issues at stake in today's debates between feminist new materialists and poststructuralist-inspired feminisms. For many feminist critics of the 1980s and 1990s, Irigaray's theorisation of fluidity was simply an expression of a "biological essentialism" that reproduced the most conventional and normative assumptions about femininity, naively celebrating the female body as a source of pure and unproblematic difference. As Claire Duchen protests, in Irigaray's work: "There is assumed to be a true, undistorted female sexuality waiting for the right time to 
emerge, like a butterfly," (1986, p.101). It is significant to note that such criticism sprang from a broader contemporaneous critique of the cultural association of the feminine with the biological, driven by recognition of the extent to which women's biology has historically been cited as justification for their exclusion from, for example, educational, economic and legal spheres. As Elaine Showalter warned: "simply to invoke anatomy risks a return to the crude essentialism that has oppressed women in the past" (1981, p.185). For Teresa de Lauretis, similarly: "there is no going back to the innocence of 'biology'" $(1987$, p.20). Such caveats are worth bearing in mind in light of feminist new materialist claims that the matter has been overlooked in feminist theory, and that the calls to turn to matter "itself" thus represents a new direction in feminist thinking. Irigaray's work, on the other hand, sees biology quite differently: she repeatedly describes her approach as a movement through or a mobilisation of traditional figures of femininity. That debates about the status of the biological in Irigaray's work were so central to its initial reception is thus important not because they represent a misreading of her work, but because they are indicative of the complex and contentious role the biological has played within the history of feminist theory.

If the role of the biological has been such a point of contention in readings of Irigaray's work, I want to suggest, it is because what is meant by the biological, and the implications of this for feminist philosophy and politics, has long been an issue of central concern and detailed discussion within feminism. We can see this further by turning to the reconsideration of Irigaray's work in the 1990s, which focused specifically on revaluating the relationship between the material or biological, on the one hand, and the cultural or linguistic, on the other, in her work. ${ }^{4}$ Arguing against earlier criticism of Irigaray's work as biologically essentialist, Jane Gallop contends that Irigaray's work does not imagine a "'body itself,' unmediated by textuality," but rather attempts to "inscribe femininity where phallocentric language fails, in catachresis" (1988, p.93). Gallop argues that Irigaray explores the catachretic nature of femininity - or rather, the construction of femininity as the catachretic element within language - as a means by which to problematise what Irigaray has referred to as the necessary "division ... between a language that is always subject to the postulates of ideality and an empirics that has forfeited all symbolisation" (1993, p.107). Judith Butler advances a very similar reading in Bodies that Matter, in which she argues that:

the feminine appears for Irigaray only in catachresis, that is, in those figures that function improperly, as an improper transfer of sense, the use of a proper name to 
describe that which does not properly belong to it, and that return to haunt and coopt the very language from which the feminine is excluded. This ... is precisely the option open to the feminine when it has been constituted as an excluded impropriety. (1993, pp. 37-38)

Given the critiques of Irigaray's work as naively essentialist in the 1980, it is significant that Butler frames her own book, published in 1993, as a response to the counter-accusation that her work focuses too relentlessly on the cultural and linguistic, at the expense of the material and biological. In an introduction that anticipates subsequent critiques of such work in feminist new materialism, she notes that she is constantly questioned: "If everything is discourse, what happens to the body? If everything is text, what about violence and bodily injury? Does anything matter in or for poststructuralism?" (p.28). ${ }^{5}$

Butler's response is not to "return" to the body or materiality as a site of pure difference or radical alterity, outside the structuring systems of normative language and thought. On the contrary, she wants to interrogate what we understand matter and materiality to mean:

In an effort to displace the terms of this debate, I want to ask how and why "materiality" has become a sign of irreducibility. ... Is materiality a site or surface that is excluded from the process of construction, as that through which and on which construction works? Is this perhaps an enabling or constitutive exclusion, one without which construction cannot operate? ... What does it mean to have recourse to materiality, since it is clear from the start that matter has a history (indeed, more than one) and that the history of matter is in part determined by the negotiation of sexual difference. We may seek to return to matter as prior to discourse to ground our claims about sexual difference only to discover that matter is fully sedimented with discourses on sex and sexuality that prefigure and constrain the uses to which that term can be put. (1993, pp. 28-29)

As we will see in the second part of the paper, such comments remain highly relevant in light of the recently renewed criticisms of post-structuralist feminism made in the context of feminist new materialism. It is significant that, although Butler's deconstruction of the perceived binary between 
matter and discourse/culture was articulated at length 25 years ago, this work (and the many others like it) is not engaged with by feminist new materialists such as Coole and Frost, who characterise such work as simply anti-materialist. As can be seen here, however, Butler's approach to materiality is driven by the same deconstructive dynamic that enables Irigaray's theorisation of fluidity and articulates a very similar critique of the assumed distinction between materiality and ideality. Thus Butler explains her aims in Bodies That Matter in the same unsettling interrogatory style as does Irigaray in "The Mechanics of Fluids," questioning:

If matter ceases to be matter once it becomes a concept, and if a concept of matter's exteriority to language is always something less than absolute, what is the status of this 'outside'? Is it produced by philosophical discourse in order to effect the appearance of its own exhaustive and coherent systematicity? What is cast out from philosophical propriety in order to sustain and secure the borders of philosophy? (1993, p.31)

Given this uncertain state of affairs, she argues presciently: "feminism ought to be interested, not in taking materiality as an irreducible, but in conducting a critical genealogy of its formation" (p.32). The shift of focus in Butler's work from materiality (as a stable referent) to materialisation (an ongoing process) is, in the first instance, consistent with the attempt to avoid what Irigaray calls "congealment" within the ruling symbolics - which would represent a consolidation of her theorisation of fluidity. In addition, it demonstrates how important the space of that putative distinction between ideality and empirics is not only to Irigaray but also to the subsequent feminists influenced by her work. In Butler's work, as in Irigaray's, bodies are understood both as having a material specificity and as a field of intersecting forces and spatio-temporal variables, as a series of dynamic processes and not a natural entity.

We see this not only in Butler's work, but also in subsequent feminist philosophy written in the 2000s. For instance, Rosi Braidotti, in Metamorphoses: Towards a Materialist Theory of Becoming, provides a nearly identical account of Irigaray's work to that found in Bodies That Matter (written a decade earlier), ${ }^{6}$ and its significance for contemporary feminisms: 
Following Irigaray, the most adequate strategy consists in working through the stock of cumulated images, concepts and representations of women, or female identity, such as they have been codified by the culture we are in. If "essence" means the historical sedimentation of many-layered discursive products, this stock of culturally coded definitions, requirements and expectations about women or female identity this repertoire of regulatory fictions that are tattooed on our skins - then it would be false to deny that such an essence not only exists, but is also powerfully operational. $(2002$, p.41)

In contemporary critical theory, continues Braidotti: "The body remains a bundle of contradictions: it is a zoological entity, a genetic data-bank, while it also remains a bio-social entity, that is to say a slab of codified, personalised memories" (p.21). Feminist philosophers like Butler and Braidotti, explicitly positioning their work in relation to Irigaray's, are concerned not to simply privilege the material, or to "return" to the body as though it had been forgotten or overlooked or as a source of radical alterity, but rather to explore the ways in which materiality and ideality are defined in an oppositional relation to one another, and the consequences - both positive and negative - of this for feminism. For the poststructuralist feminists influenced by Irigaray's work, there is no matter but only materialisation, a continual process that makes, somewhat paradoxically, transformation a constant feature of embodied existence and subjectification. As Margrit Shildrick notes, "bodies, rather than being material and graspable from the start, are materialised through a set of discursive practices" (2002, p.10). Citing Butler's claims that "there is no reference to a pure body which is not at the same time a further formation of that body," Shildrick argues: "The body, then, is not a prediscursive reality, but rather a locus of production, the site of contested meaning, and as such fluid and unstable, never given and fixed" (2002,p. 10).

\section{New Materialisms, Old Debates}

Given how central this discussion about the complex and mutually constitutive relationship between body and culture, materiality and language, has been to feminist thought, it is curious that the emergence of new materialism is so often framed as a return to a materiality that has been thoroughly overlooked and neglected in contemporary critical theory. This is a claim that has been gaining increasing critical traction, and can be found widely articulated in feminist work that, while it does not identify as new materialist, is clearly informing emergent work in this field. We see it 
expressed in Stacey Alaimo and Susan Hekman's contention that: "The guiding rule of procedure for most contemporary feminisms requires that one distance oneself as much as possible from the tainted realm of materiality by taking refuge within culture, discourse, and language" (2008, p.1). It can be seen also in Elizabeth Grosz's exhortation that we need to "'return' to concepts of nature, matter, life" because "[w]e have forgotten the nature, the ontology, of the body" (2004, p.2). We see it too in Vivian Sobchack's call for a more phenomenological approach to film criticism:

despite the current academic fetishization of "the body," most theorists still don't know what to do with their unruly responsive flesh and sensorium. Our sensations and responses pose an intolerable question to prevalent linguistic and psychoanalytic understandings of the cinema as grounded in conventional codes and cognitive patterning ... [C]ontemporary film theory has had major difficulties in comprehending how it is possible for human bodies to be, in fact, really "touched" and "moved" by the movies. (2004,p. 59)

For Karen Barad, contemporary feminist studies of matter and materialism remain too often entrenched in a "representationalism" that reproduces an "ontological gap" between word and thing. In a critique that circles back to the concerns that motivate Irigaray's study of the relationship between ideality and empirics, Barad argues: "representationalism is the belief in the ontological distinction between representations and that which they purport to represent; in particular, that which is represented is held to be independent of all practices of representing. That is, there are assumed to be two distinct and independent kinds of entities - representations and entities to be represented" (2003, p. 804). She concludes: "Representationalism separates the world into the ontologically disjoint domains of words and things, leaving itself with the dilemma of their linkage such that knowledge is possible" (203, p. 811). As Coole and Frost write in their introduction to the collection New Materialisms, the purpose of this field is, precisely, to address such critical oversight:

Our commitment to editing a book on the new materialisms at this time springs from our conviction that materialism is once more on the move after several decades in abeyance. Everywhere we look, it seems to us, we are witnessing 
scattered by insistent demands for more materialist modes of analysis and for new ways of thinking about matter and processes of materialisation. $(2010$, p.2)

This argument that feminism in particular, and critical theory in general, has concentrated its attention on "language, consciousness, subjectivity, agency, mind [and] soul ... as idealities fundamentally different from matter and valorised as superior to the base desires of biological material or the inertia of physical stuff" $(2010$, p.2) has been met with frank incredulity by feminists seeped in the history of feminist philosophy glossed in the first part of this article, and in which, as Irigaray's work demonstrates, such a distinction has been the object of deconstructive critique. As Sara Ahmed argues in "Imaginary Prohibitions: Some Preliminary Remarks on the Founding Gestures of the 'New Materialism,'" debates about materialism have never ceased to play a central role in the direction of feminist theory. Materialism, Ahmed argues, is one of the key terms around which feminist theory has always oriented itself. The new materialist claim that feminism needs to "return" to a materiality that a previous "cultural turn" has encouraged us to overlook itself reproduces a "familiar or even habitual anxiety that feminism and poststructuralism have reduced 'everything' to language and culture, in what is often referred to as 'textualism,' and have forgotten the 'real' of the real world, or the materiality of what is given. As a reviewer of papers for journals," she writes, "I have lost count of the number of papers that have referred casually, usually without using examples, to how feminism or poststructuralism have not dealt with the body as a real, living, physical, biological entity or have reduced 'everything' to language, signification and culture" (2008, p.25). The claim that critical theory has neglected or forgotten the body, Ahmed argues, itself represents an astonishing act of forgetting, one that seems based on a wilful amnesia: "you can only argue for a return to biology by forgetting the feminist work on the biological, including the work of feminists trained in the biological sciences. In other words, you can only claim that feminism has forgotten the biological if you forget this feminist work" (p.27).

This argument is continued in Nikki Sullivan's "The Somatechnics of Perception and the Matter of the Non/human: A Critical Response to the New Materialism," published in 2012. Sullivan writes:

Like Sara Ahmed ... I am increasingly frustrated by the claim, repeated of late with a mantra-like monotony, that (usually nameless) feminists and/or social constructionists - even those whose work appears to focus on 'the body' - routinely 
ignore the matter of corporeal life. ... [W] [Wat makes me uncomfortable is not a materialist conception of being-in-the-world, but rather, the distinction between "culture" and "matter" (as discernable elements) which ... is engendered by the new materialist perception of poststructuralist feminism(s) which constitutes what it purports to merely "observe". (pp.300-01) ${ }^{7}$

Dennis Bruining's recent "A Somatechnics of Moralism: New Materialism or Material Foundationalism," further interrogates the assumed distinction between matter and culture in this work, arguing for the importance of seeing these as a mutually constitutive somatechnics. Matter and materiality, he writes:

are not awaiting their discovery in a "state", rather, they are the product of, constituted in and through, regulatory and discursive practices which spawn the processes in which they materialise; to think otherwise is to ignore the context in which such materialisation takes place. ... What Butler, Shildrick and Sullivan illustrate is that bodies, matter, things, and so on, are most certainly material, but that an investigation into their materiality always-already and with no exception involves a construction of that (knowledge of) materiality, and this construction reciprocally informs and is informed by the situated position of the investigating subject; in other words, matter in its own right, or, matter as such, does not exist. (2013, pp.161-162) $)^{8}$

Moreover, in a context in which, as Nik Rose has recently argued, we are witnessing a widespread return to biologised understandings of the self, many of which can be seen to reproduce very nineteenth-century models of biological determinism (2006), calls for a return to the biological might be seen as consistent with, rather than resistant to, popular assumptions about materiality and biology.

Rather than attempting to resolve the debate between poststructuralist and new materialist feminisms, I would like to suggest - in the spirit of Irigaray's careful deconstruction of such apparently polarised positions - a new perspective on the source this contention. The increasingly entrenched opposition between these two positions might be productively reframed as evidence of 
a sense of critical urgency to reconsider the role and nature of the material in a context of rapid cultural and epistemological change, one that is redefining how we both understand and experience materiality. As Beatriz Preciado has recently argued, the contemporary body "is not a passive living material but an techno-organic interface, a techno-living system segmented and territorialised by different political models (textual, computerised, biochemical)" (2008, p.108). In this way, the "new" in "new materialism" might be reinterpreted, not as a corrective (re)turn to a materiality that feminism has overlooked, but as an attempt to come to terms with new and emergent forms of materiality itself. ${ }^{9}$ Materiality, like culture and because of it, does not exist in an absolute unchanging state, outside history and thought. This is the point that Bennett and Barad have made so influentially. For Preciado - along with manner others, like Rose, working in the area of contemporary biopolitics - the matter of the contemporary body is being actively remade by new regimes of pharmaceutics and biotechnologies. Catherine Waldby has described the increasing commercial and medical use of bio-matter as part of an emergent "tissue economy." For Oron Catts and lonat Zurr, the contemporary laboratory is a source of new kinds of living systems: artificially produced and technological dependent kinds of matter that are best understood as "semi-living" or "partially alive." The emergence of feminist new materialism might hence be understood not as an attempt to redress the oversight of earlier feminisms, but as a response to such radical shifts in the nature of matter itself.

\section{Conclusion}

It is for this reason that Irigaray's work remains so important. When Irigaray speaks of fluidity, as we have seen above, she is fully conscious of the dangers it poses as well as the possibilities it enables. While the logic of the "ruling symbolics" sees both language and philosophy as fully abstract and uncontaminated by the material, Irigaray argues that language and philosophy are always and inevitably informed by a materiality itself mediated by, and materialised through, the discursive practices by which it is constituted. As Irigaray argues at the start of "The Mechanics of Fluids," the properties of fluidity mean that it is dilutable as well as diluting, passive as well as active, something that reflects and even exacerbates the conditions in which women are constituted as the mute outside of a phallocentric culture as well as the means by which they may exert the pressure of their uncontainable indeterminacy and multiplicity on the systematicity of that culture. 
For Irigaray, then, fluidity is not unproblematically or unequivocally aligned with the positive and progressive; rather, its dynamic nature, its conceptualisation as a field of forces, means that one must pay attention to the specific instances of each manifestation, instead of making generalising assumptions about its effects. Fluidity may enable a "transgression and confusion of boundaries" but it does so always as part of the (very conventional) construction of femininity, and of the materiality it represents, as essentially other to the logic and rationality of the "ruling symbolics." Thus fluidity, while important and central, while a site of possible strategic appropriation, always remains a potentiality whose outcome, by its very nature, can never be determined in advance.

\section{Notes}

${ }^{1}$ As Elizabeth Grosz notes in Volatile Bodies: Towards a Corporeal Feminism, seminal fluidity is the strange exception here; rarely subject to any discussion at all, she argues, male fluidity is instead displaced onto the female body (1994). For a detailed discussion of seminal fluidity, see my Queer Writing: Homoeroticism in Jean Genet's Fiction (2009).

2I use the term "feminist new materialism" here as most of the new materialist texts examined in this paper are by feminist writers, and to distinguish the work referred to here from the sort of "new materialism" described, for instance, in Jussi Parikka's What is Media Archeology?, which examines German media archeology under this rubric.

${ }^{3}$ In "Così Fan Tutti", she further cites Lacan's notorious claim that: "There is no woman who is not excluded by the nature of things, which is the nature of words, and it must be said that, if there is something they complain a lot about at the moment, that is what it is - except that they don't know what they are saying, that's the whole difference between them and me" (1993, p.87).

${ }^{4}$ See, for instance, Diana Fuss's Essentially Speaking: Feminism, Nature and Difference (1989), Naomi Schor and Elizabeth Weed's The Essential Difference (1994) and Judith Butler's Bodies that Matter (1993).

${ }^{5}$ A full decade later, Karen Barad would reiterate this criticism in nearly identical terms. In recent feminist work, she writes: "Language matters. Discourse matters. Culture matters. There is an important sense in which the only thing that does not seem to matter anymore is matter" (2003, p. 801). In a critique of performativity that does not explicitly cite Butler, Barad continues: "properly construed, [performativity] is not an invitation to turn everything (including material bodies) into words; on the contrary, performativity is precisely a contestation of the excessive power granted to language to determine what is real. Hence, in ironic contrast to the misconception that would equate performativity with a form of linguistic monism that takes language to be the stuff of reality, performativity is actually a contestation of the unexamined habits of mind that grant language and other forms of representation more power in 
determining our ontologies than they deserve" (2003, p. 802).

6 It should be noted, however, that Braidotti critiques Butler's conception of materiality in Bodies that Matter as deeply flawed. She argues that the Hegelian roots of Butler's argument renders the Irigarayan body overly material, thus ignoring the realm of bodily experience so important to Irigaray (Braidotti: 2002, pp. 42-45). Butler has also criticized Braidotti's Deleuzean perspective on materiality in Undoing Gender (p. 200). For further discussion of the Butler-Braidotti debate on materiality see Mikko Tuhkanen's 'Performativity and Becoming' (2009) and Karin Sellberg's 'Transitions and Transformations' (2009).

${ }^{7}$ As Sullivan notes, the idea of "somatechnics" was devised precisely as a way to try to rethink this putative binary opposition in a more productive way. She explains: "A few years ago, a number of colleagues and I coined the term somatechnics in order to highlight what we see as the inextricability of soma and techné, of bodily-being-in-the- world, and the dispositifs in and through which corporealities, identities and difference(s) are formed and transformed, come to matter, if you like. Somatechnics, then, supplants the logic of the 'and' (thereby moving beyond instrumentalist logic), suggesting that technés are not something that are added or applied to 'the body', nor are they simply tools the already-constituted body-subject manipulates to its own ends. Rather, technés - in the Heideggerian sense - are techniques and/or orientations (ways of seeing, know- ing, feeling, moving, being, acting and so on) which are learned within a particular tradition or ontological context (are, in other words, situated), and function (often tacitly) to craft (un)becoming-with in very specific ways. Perception, then, is both the vehicle and effect of a particular situated somatechnics, an orientation to the world in which the l/eye is always-already co-implicated, co-indebted, co-responsible" (2012, p.303).

${ }^{8}$ Earlier concerns about precisely this issue are articulated in Jussi Parikka and Milla Tiainen's opening address to the "New Materialism and Digital Culture" conference, held at Anglian Ruskin University in 2010: "the new materialist conceptions of dynamic human and non-human materialities that acquire shapes, operate and differentiate also beyond human perception and discursive representational systems are, at least within feminist new materialisms, in danger of positing matter as an it-like fetish object precisely because of their insistence on its ontological distinctiveness. ... [D]espite intentions to the contrary many new materialist gestures actually solidify rather than 'fluidify' the boundaries between nature/culture and matter/signification".

${ }^{9}$ A part of the problem here, I would contend, derives from the poverty of rhetoric in so much contemporary critical writing, in which the value of any particular kind of scholarship is always asserted in relation to what previous writers have "failed" to think of, or in contrast to work that "does not go far enough." Novelty in the face of previous critical neglect is not the only way to establish the value of scholarship, and is often simply not accurate or persuasive. A more generous critical relationship, in which previous work in a field is acknowledged and built on, would seem more consistent with the aims of feminism, and more conducive to productive dialogue between different fields and approaches. 


\section{Bibliography}

Ahmed, S., 2008. Some Preliminary Remarks on the Founding Gestures of the "New Materialism". European Journal of Women's Studies, 15(23), pp.23-39.

Alaimo, S. and Hekman, S., eds, 2008. Material Feminisms. Bloomington: Indiana University Press.

Barad, K., 2003. "Posthumanist Performativity: Toward an Understanding of How Matter Comes to Matter," Signs: Journal of Women in Culture and Society 28.3

- 2007. Quantum Physics and the Entanglement of Matter and Meaning. Durham: Duke University Press.

Bell, S., 2010. Fast Feminism. New York: Autonomedia.

Bennett, Jane. Vibrant Matter: A Political Ecology of Things. Durham and London: Duke University Press, 2010.

Bobel, C., 2010. New Blood: Third-Wave Feminism and the Politics of Menstruation. New Brunswick, NJ: Rutgers University Press.

Braidotti, R., 2002. Metamorphoses: Towards a Materialist Theory of Becoming. Cambridge: Polity Press.

Bruining, D., 2013. A Somatechnics of Moralism: New Materialism or Material Foundationalism. Somatechnics, 3(1), pp.149-168.

Butler, J., 1993. Bodies that Matter: On the Discursive Limits of "Sex". New York: Routledge.

__., 2004. Undoing Gender. New York: Routledge.

Catts, Oron and lonat Zurr, eds. Partial Life. Open Humanities Press, 2011.

Duchen, C., 1986. Feminism in France: May '68 to Mitterand. London and Boston: Routledge and Kegan Paul.

Elkins, J., 2001. Pictures and Tears: A History of People Who Have Cried in Front of Paintings. London: Routledge.

Fuss, D., 1989. Essentially Speaking: Feminism, Nature and Difference. New York: Routledge.

Gallop, J., 1988. Thinking Through the Body. New York: Columbia University Press.

Giles, F., 2003. Fresh Milk: The Secret Life of Breasts. Sydney: Allen and Unwin.

Grosz, E., 1994. Volatile Bodies: Towards a Corporeal Feminism. Indianapolis: Indiana University Press.

- 2004. The Nick of Time: Politics, Evolution and the Untimely. Durham, NC: Duke University Press.

Irigaray, L., 1993 [1974]. Speculum of the Other Woman. Trans. G. C. Gill. Ithaca, NY: Cornell University Press. 
—. This Sex Which Is Not One. Trans. C. Porter with C. Burke. Ithaca, NY: Cornell University Press.

de Lauretis, T., 1987. Technologies of Gender: Essays on Theory, Film, And Fiction. Bloomington, IN: Indiana University Press.

Lutz, T., 2001. Crying: A Natural and Cultural History of Tears. New York: Norton.

Parikka, J., 2012. What is Media Archeology? London: Polity Press.

Parikka, J. and Tiainen, M., 2010. Opening Address. Presented at: The New Materialism and Digital Culture Symposium. Anglia Ruskin University, Cambridge, 21 June.

Preciado, B., 2008. Testo Junkie: Sexe, Drogue et Biopolitique. Paris: Grasset.

Coole, D., and Frost, S., eds, 2010. New Materialialisms: Ontology, Agency, and Politics. Durham, NC: Duke University Press.

Rose, N., 2006. The Politics of Life Itself: Biomedicine, Power, and Subjectivity in the Twenty-first Century. Princeton, NJ: Princeton University Press.

Rosewarne, L., 2012. Periods in Pop Culture: Menstruation in Film and Television. Maryland and Plymouth: Lexington Books.

Schor, N. and Weed, E., eds, 1994. The Essential Difference. Bloomington: Indiana University Press.

Sellberg, K., 2009. Transitions and Transformations: From Gender Performance to Becoming Gendered. Australian Feminist Studies 24(59), pp. 71-84.

Shildrick, M., 2002. Embodying the Monster: Encounters With the Vulnerable Self. London: Sage.

Showalter, E., 1981. Feminist Criticism in the Wilderness. Critical Inquiry 8(2), pp.181-187.

Sobchack, V., 2004. Carnal Thoughts: Embodiment and Moving Image Culture. Berkeley, CA: University of California Press.

Stephens, E., 2009. Queer Writing: Homoeroticism in Jean Genet's Fiction. London and New York: Palgrave Macmillan.

Sullivan, N., 2012. The Somatechnics of Perception and the Matter of the Non/Human: A Critical Response to the New Materialism. European Journal of Women's Studies 19(3), pp.299-313.

Tuhkanen, M., 2009. Performativity and Becoming. Cultural Critique 72, pp. 1-35.

Waldby, Catherine and Robert Mitchell. Tissue Economies: Blood, Organs and Cell Lines in Late Capitalism. UK: Duke University Press, 2006. 